\title{
KONSELING BEHAVIOR DENGAN TEKNIK OVERCORRECTION UNTUK MEGURANGI PERILAKU MEMBOLOS SISWA
}

\author{
Oleh: Mulkiyan ${ }^{1}$ \\ ${ }^{1}$ Institut Agama Islam Muhammadiyah Sinjai, \\ Jl. Sultan Hasanuddin, No. 20 Balangnipa, Sinjai \\ E-Mail: Mulkiyan9296@gmail.com, TIp.:085398930350
}

\begin{abstract}
$* * *$
Abstrak

Tulisan ini bertujuan untuk memperkenalkan dan menjelaskan tentang konseling behavior dengan tehnik overcorrection dalam mengurangi perilaku membolos siswa. Adapun sasaran tulisan ini adalah lembaga-lembaga pendidikan, sekolah, guru/tenaga pengajar, para orang tua untuk memberikan pembinaan dalam membentuk perubahan sikap kearah yang dari maladaptif menuju sikap dan perilaku adaptif. Secara ringkas, dari tulisan ini dapat dipahami tentang penerapan konseling behavior dengan tehnik overcorrction, tahapan proses dan tujun dalam mengurangi perilaku membolos siswa yang terdiri dari, pertama: melakukan asesmen (assessment), kedua: menentukan tujuan (goal setting), ketiga: mengimplementasikan teknik (technique implementation), keempat: evauasi mengakhiri konseling (evaluation termination). Dengan adanya tulisan ini diharapkan para guru, orang tua dan umumnya terhadap masyarakat dapat mendampingi anak didiknya agar tidak terjerumus dalam perilaku-perilaku yang tidak dibenarkan baik secara moral dan agama. Adapun jenis penelitian yang digunakan dalam penelitian ini yaitu jenis penelian kepustakaan (library research).
\end{abstract}

\section{Kata Kunci: Konseling Behavior, Tehnik Punishment Overcorrection, Perilaku Membolos}

\section{PENDAHULUAN}

$\mathrm{P}$ endidikan adalah usaha sadar dan terencana untuk mewujudkan suasana belajar dan pembelajaran agar peserta didik secara aktif mengembangkan potensi dirinya untuk memiliki kekuatan spiritual keagamaan, pengendalian diri, kepribadian, kecerdasan, akhlak mulia serta keterampilan yang diperlukan dirinya, masyarakat, bangsa dan Negara (UU No 20 Tahun 2003). Hal ini juga dikemukakan oleh Driyarkara yang menyatakan bahwa pendidikan adalah upaya memanusiakan manusia muda ketaraf insani harus diwujudkan dalam seluruh proses atau upaya pendidikan. Sekolah merupakan bagian dari pendidikan. Di setiap sekolah kegiatan belajar mengajar berlangsung, ilmu pengetahuan diajarkan dan dikembangkan kepada anak didik. Kegiatan belajar mengajar di sekolah merupakan kegiatan inti dalam pendidikan di sekolah. Segala sesuatu yang telah diprogramkan akan dilaksanakan dalam kegiatan belajar mengajar. Melalui kegiatan belajar mengajar ini juga proses transfer dan transformsi ilmu pengetahuan dapat diberikan kepada peserta didik. Kegiatan belajar mengajar merupakan terjadinya interaksi antara guru dengan siswa dalam rangka menyampaikan bahan pelajaran kepada siswa untuk mencapai tujuan pengajaran (Suryosubroto, 2009: $30)$.

Komponen inti dalam kegiatan belajar mengajar adalah guru dan peserta didik. Proses belajar mengajar dapat terlaksana apabila kedua komponen tersebut ada. Jika salah satu komponen tidak hadir 
maka proses belajar mengajar tersebut tidak akan terjadi. Sehingga proses transfer ilmu pengetahuan kepada peserta didik tidak dapat dilakukan. Melihat pandangan diatas tentunya dapat diketahui bahwa kehadiran komponen inti dalam proses kegiatan belajar mengajar sangatlah penting. Namun, melihat fenomena dilapangan saat ini menunjukkan hal berbeda. Saat ini banyak ditemukan sekali salah satu komponen inti dari kegiatan belajar mengajar tidak hadir dalam kegiatan belajar mengajar. Salah satu contoh bentuk persoalan tersebut adalah perilaku membolos siswa. Saat ini banyak sekali ditemukan siswa yang tidak hadir mengikuti kegiatan belajar mengajar di sekolah pada saat jam pelajaran. Sering kali pada saat jam pelajaran mereka terlihat bermain di tempat sekitar sekolah seperti kantin, dan ditempat diluar sekolah seperti dirental playstation ataupun mall. Membolos merupakan salah satu bentuk dari kenakalan siswa, yang jika tidak segera diselesaikan atau diatasi dapat menimbulkan dampak yang lebih parah. Di Amerika Serikat membolos adalah masalah yang mulai meresahkan, karena menurut beberapa penelitian perilaku membolos sangat dipercaya sebagai prediktor munculnya perilaku delinkuen pada remaja (studi mencatat $75-85 \%$ pelaku kenakalan remaja adalah yang suka membolos atau sangat sering absen dari sekolah). Di Amerika Serikat, siswa yang membolos disebut sebagai person in need of supervision (PINS) atau orang yang membutuhkan pengawasan akademis siswa yang ke sekolah tetapi sering membolos akan menanggung resiko kegagalan dalam belajar. Selain itu bagi siswa yang gemar membolos dapat terlibat dengan hal-hal yang cenderung merugikan, mulai dari pencandu narkotika, pengagum free sex dan mengidolakan tindak kekerasan atau dengan istilah lain adalah tawuran.

\section{Metode Penelitian}

Jenis penelitian yang digunakan penulis adalah jenis penelitian kepustakaan (library research), yaitu serangkaian kegiatan yang berkenaan dengan meode pengumpulan data pustaka (Mahmud, 2011: 32). Menurut Abdul Rahman Sholeh, penelitian kepustakaan (library research) ialah penelitian yang menggunakan cara untuk mendapatkan datainformasi dengan menempatkan fasilitas yang ada di perpustakaan, seperti buku, majalah, dokumen, catatn kisah-kisah sejarah (Abdul Rahman Sholeh, 2005: 63).

\section{PEMBAHASAN}

\section{A. Pengertian Perilaku Membolos}

Azwar menyebutkan bahwa perilaku adalah reaksi terhadap stimulus yang bersifat sederhana maupun kompleks. Berdasarkan pengertian tersebut dapat disimpulkan bahwa perilaku merupakan reaksi seorang individu terhadap adanya stimulus guna mencapai suatu tujuan (Saifuddin Azwar, 2003: 9).

Gunarsa menyebutkan bahwa perilaku membolos adalah pergi meninggalkan sekolah tanpa sepengetahuan pihak sekolah. Pengertian lain menyebutkan bahwa perilaku membolos dapat diartikan 
sebagai anak yang tidak masuk sekolah dan anak yang meninggalkan sekolah belum usai tanpa izin (Singgih Gunarrsa, 1981: 31).

Dari beberapa pengertian tersebut diatas maka diperoleh kesimpulan bahwa perilaku membolos merupakan sebuah perilaku tidak masuk sekolah ataupun meninggalkan sekolah yang dilakukan tanpa sepengetahuan pihak sekolah dan tanpa izin yang jelas, dan dilakukan untuk mencapai suatu tujuan tertentu.

\section{B. Gejala Siswa Membolos}

Menurut Prayitno dan Erman Amti ada beberapa gejala siswa membolos antara lain yaitu: (Prayitno dan Erman Amti, 2004: 61). a. Berhari-hari tidak masuk sekolah b. Tidak masuk sekolah tanpa izin c. Sering keluar pada jam pelajaran tertentu d. Tidak masuk kembali setelah minta izin e. Masuk sekolah berganti hari f. Mengajak teman-teman untuk keluar pada mata pelajaran yang tidak disenangi g. Minta izin keluar dengan berpura-pura sakit atau alasan lainnya h. Mengirimkan surat izin tidak masuk dengan alsan yang dibuat- buat i. Tidak masuk kelas lagi setelah jam istirahat Berbagai gejala tersebut merupakan gejala yang secara umum ditunjukkan oleh sebagian besar siswa yang memilki kebiasaan membolos sekolah. Akan tetapi dalam hal ini antara siswa yang satu dengan yang lain menunjukkan gejala yang berbeda atau tidak sama dalam perilaku membolosnya.

\section{Faktor-faktor Penyebab Siswa Membolos}

Perilaku membolos pada dasarnya dipengaruhi oleh banyak faktor. Menurut Prayitno ada beberapa faktor yang mempengaruhi siswa untuk membolos antara lain yaitu: (Prayitno dan Erman Amti, 2004: 61) a. Tidak senang dengan sikap dan perilaku guru b. Merasa kurang mendapatkan perhatian dari guru c. Merasa dibeda-bedakan oleh guru d. Merasa dipojokkan oleh guru e. Proses belajar mengajar membosankan f. Merasa gagal dalam belajar g. Kurang berminat terhadap pelajaran h. Terpengaruh oleh teman yang suka membolos i. Takut masuk karena tidak membuat tugas j. Tidak membayar kewajiban (SPP) tepat pada waktunya Perilaku membolos yang dilakukan oleh siswa pada dasarnya tidak hanya dilatar belakangi karena faktor sekolah saja tetapi ada faktor lain yang juga menjadi penyebab perilaku membolos.

Menurut Supriyo ada kemungkinan-kemungkinan penyebab dan latar belakang timbulnya kasus ini, antara lain: (Supriyo, t.th.: 112). a. Orang tua kurang memperhatikan anak-anaknya b. Orang tua terlalu memanjakan anaknya c. Orang tua terlalu buas terhadap anaknya d. Pengaruh teman e. Pengaruh mass media (film, wanita.) f. Anak yang belum sadar tentang kegunaan sekolah g. Anak yang belum ada tanggung jawab terhadap studinya Dari kedua pendapat diatas dapat simpulkan bahwa pada dasarnya ada tiga faktor utama yang menjadi penyebab munculnya perilaku membolos. Faktor tersebut adalah faktor pribadi, faktor keluarga dan faktor sekolah.

\section{Dampak Negatif Perilaku Membolos}


Perilaku membolos apabila tidak segera di atasi maka dapat menimbulkan banyak dampak negatif. Supriyo menyatakan bahwa apabila orang tua tidak mengetahui dapat berakibat anak berkelompok dengan teman yang senasib dan membutuhkan kelompok/ group yang menjurus ke halhal yang negative (gang), peminum, ganja, obat-obat keras, dan lain-lain. Dan akibat yang paling fatal adalah anak akan mengalami gangguan dalam perkembangannya dalam usaha untuk menemukan identitas dirinya (manusia yang bertanggung jawab) (Supriyo, t.th.: 112).

Sementara menurut Prayitno perilaku membolos dapat menimbulkan beberapa dampak negatif antara lain yaitu: a. Minat terhadap pelajaran akan semakin berkurang b. Gagal dalam ujian c. Hasil belajar yang diperoleh tidak sesuai dengan potensi yang dimilki d. Tidak naik kelas e. Penguasaan terhadap materi pelajaran tertinggal dari teman-teman lainnya f. Dikeluarkan dari sekolah Dari kedua pendapat tersebut maka dapat disimpulkan bahwa membolos merupakan perilaku yang tidak hanya membawa dampak pada kegagalan dalam belajar seperti gagal dalam ujian dan tidak naik sekolah, tetapi juga dapat membawa dampak yang lebih luas seperti terlibat dengan hal-hal yang cenderung merugikan lainya, mulai dari pencandu narkotika, pengagum freesex dan mengidolakan tindak kekerasan atau dengan istilah lain adalah tawuran.

\section{E. Konseling Behavior}

\section{Pengertian Konseling Behavior}

Menurut Prayitno dan Erman Anti konseling adalah proses pemberian bantuan yang dilakukan melalui wawancara konseling oleh seorang ahli (disebut konselor) kepada individu yang sedang mengalalmi suatu maslah (disebut klien) yang bermuara pada teratasinya masalah yang dihadapi oleh klien (Prayitno dan Erman Amti, 2004: 100)

Behaviorisme adalah suatu pandangan ilmiah tentang tingkah laku manusia. Konseling behavioral dikenal juga dengan modifikasi perilaku yang dapat diartikan sebagai tindakan yang bertujuan untuk mengubah perilaku. Dalam konsep behavioral, perilaku manusia merupakan hasil belajar, sehingga dapat diubah melalui manipulasi dan mengkreasi kondisi-kondisi belajar. Meurut pandangan behavioristik, setiap orang dipandang memiliki kecenderungan positif dan negatif yang sama. Manusia pada dasarnya dibentuk dan ditentukan oleh lingkungan sosial budayanya. Dari penjelasan tersebut maka konseling behavioral merupakan proses pemberian bantuan yang dilakukan oleh konselor kepada klien yang dilakukan melalui wawancara konseling dengan pendekatan behavioral yang bermuara pada teratasinya masalah yang dihadapi klien (Gantina Komalasari, 2011: 152).

\section{Tujuan Konseling Behavioral}

Pada dasarnya terapi tingkah laku diarahkan pada tujuan-tujuan tingkah laku baru/penghapusan tingkah laku yang maladaptif serta memperkuat dan mempertahankan tingkah laku yang diinginkan (Gerald Corey, 2005: 197). Tujuan konseling behavioral berorientasi pada perubahan atau modifikasi perilaku konseli sebagai berikut: menciptakan 
kondisi-kondisi baru bagi proses belajar, penghapusan hasil belajar yang tidak adaktif, membantu konseli membuang respons-renspons yang lama yang merusak diriatau maladaptif dan mempelajari renspons-renspons yang baru yang lebih sehat dan sesuai.

3. Peran dan fungsi konselor

Peran konselor dalam konseling behavioral sangat berperan aktif, direktif dan menggunakan pengetahuan ilmiah untuk menemukan solusi dari persoalan individu. Konselor bihavioral biasanya berfungsi sebagai guru, pengarah dan ahli yang mendiagnosa tingkah laku yang maladaptive dan menentukan prosedur yang mengatasi persoalan tingkah laku individu. Selain itu konselor juga sebagai model bagi kliennya.

Seorang konselor dapat mengambil beberapa peranan, bergantung pada orientasi tingkah lakunya dan tujuan lien. Bagaimanapun juga, umumnya konselor yang memakai teknik tingkah laku, aktif di dalam sesi konseling. Sebagai hasilnya, klien belajar, tidak belajar, atau mempelajari ulang cara berperilaku yang spesifik. Dalam proses itu, konselor berfungsi sebagai konsultan, guru, penasehat, fasilitator, dan pendukung (Samuel T. Gladding, 2012: 261).

4. Tahap-tahap konseling behavior

Tingkah laku yang bermasalah dalam konseling behavior adalah tingkah laku yang berlebihan (excessive) dan tingkah laku yang kurang (deficit). Tinglah laku yang berlebihan seperti: merokok, terlalu banyak main games, dan sering memberi komentar di kelas. Adapun tingkah laku yang deficit adalah terlambat masuk sekolah, tidak mengerjakan tugas dan bolos sekolah. Tinkah laku excessive dirawat dengan menggunakan teknik konseling untung menghilangkan atau mengurangi tingkah laku, sedangkan tingkah laku deficit diterapi dengan menggunakan teknik meningkatkan tingkah laku.

Konseling behavioral memiliki empat tahap yaitu pertama: melakukan asesmen (assessment) tahapan ini bertujuan untuk menentukan apa yang dilakukan oleh konseli pada saat ini. Asesmen dilakukan adalah aktivitas nyata, perasaan dan pikiran koneseli, kedua: menentukan tujuan (goal setting) konselor dan konseli menentukan tujuan konseling ssuai dengan kesepakatan bersama berdasarkan informasi yang telah disusun dan dianalisis, tahap ini disusun atas tiga dasar langkah yaitu membantu konseli untuk memandang masalahnya atas dasar tujuan-tujuan yang diinginkan, memperhatikan tujuan konseli berdasarkan kemungkinan hambatan-hambatan situasional tujuan belajar yang dapat diterima dan dapat diukur dan memecahkan tujuan ke dalam sub-tujuan dan menyusun tujuan menjadi susunan yang beruntun, ketiga: mengimplementasikan teknik (technique implementation) setelah tujuan konseling dirumuskan konselor dan konseli menentukan strategi belajar yang terbaik untuk membantu konseli mencapai perubahan tingkah laku yang diinginkan. Konsleor dan konseli mengimplementasikan teknik-teknik konseling sesuai dengan masalah yang dialami oleh konseli, keempat: evauasi mengakhiri konseling (evaluation termination) merupakan proses yang berkesinambungan. Evaluasi dibuat atas dasar apa yang konseli perbuat. Tingkah laku 
konseli digunakan sebagai dasar untuk mengevaluasi efektivitas konselor dan efektivitas tertentu dari teknik yang digunakan (Gantina Komalasari, 2011: 160).

\section{Teknik Konseling Overcorrection}

\section{a. Konsep Dasar}

Overcorrection awalnya dikembangkan oleh Foxx dan Azrin pada awal 1970-an sebagai sebuah tehnik untuk mengeliminasi prilaku maladatif sekaligus meredukasi individu, dengan demikian banyak literature klasik tentang tehnik dan hasil penelitian. Ovorcorrection melibatkan dua komponen: restitusi dan praktik positif. Restitusi mengharuskan individu untuk memulihkan situasi yang terganggu ke kondisi yang sama atau bahkan lebih baik dibanding sebelumnya, dan praktik positif melibatkan latihan perilaku secara berulang-ulang untuk situasi yang sama. Contohnya jika seorang anak membantingkan pintu, orang tuanya dapat didorong untuk menyuruh anaknya minta maaf dan setelah itu latihan membuka dan menutup pintu tanpa bersuara saat masuk dan keluar sebanyak 10 kali, atau selama jangka waktu tertentu, misalnnya lima menit. Latihan positif berulang-ulang memiliki efek membuat hukuman.

Overcorrection adalah sebuah bentuk hukuman, tetapi ia tidak mengikuti sebuah teori tertentu, akan tetapi berbeda dengan bentuk hukuman lainnya overcorrection tidak sewenang-wenang, ia mengajari individu untuk bertanggung jawab atas perbuatannya dan mengakui dampak tindakannya pada orang lain. Restitusi dirancang untuk mengajarakan konsekuensi wajar dari prilaku buruk, dan praktik postif mengajarkan yang baik, sehingga berfungsi sebagai langkah preventif (Bradley T. Efiord, 2016: 464).

b. Teknik

Sebelum menggunakan teknik konseling overcorrection, metode-metode reinforcement positif seharusnya dicobakan sebagai upaya membentuk prilaku individu. Akan tetapi, jika reinforcement positif tidak berhasil, overcorrection dapat di implementasikan. Ada empat langkah yang dapat digunakan dalam tehnik overcorrection. Pertama, konselor professional harus mengidentifikasi prilaku target maupun prilaku alternatif yang diajarkan melalui latihan positif. Ketika prilaku target dilakukan, konselor professional seharusnya segera memberi klien bahwa prilaku tersebut tidak baik dan memerintahkan klien untuk berhenti. Kedua, konselor profesional seharusnya memandu klien secara verbal untuk menjalani prosedur overcorrection, dengan mengintruksikan klien menyelesaikan restitusi dan setelah itu menajalani praktik positif melalui pengulangan dengan jumlah tertentu. Bilamana perlu, konselor profesional dapat memandu klien secara manula menjalani prosedur overcorrection dengan menggunakan sedikit mungkin pakasaan. Ketiga, individu diizinkan untuk kembali kegiatan sebelumnya. 
Dalam penelitian klasik mereka, Foxx dan Azrin membuat beberapa rekomendasi untuk penggunaan efektif overcorrection. Restitusi seharusnya dikaitkan secar langsung dengan prilaku buruk. Di samping itu, restitusi seharusnya dilakukan segera setelah prilaku buruk untuk dua hasil. Pertama, prilaku buruk pada akhirnya seharusnya mencapai extinction (hilang) karena kilen tidak akan punya waktu untuk menikmati efekefek prilaku buruknya. Kedua, prilaku buruk yang akan datang seharusnya ditekan karena konsekuensi negative segera lebih efektf dibandingkan konsekuensi non-segera. Di samping itu, restitusi seharusnya dipepanjang durasinya. Terakhir, individu seharusnya dilibatkan secara aktif dalam melakukan restitusi dan seharusnya berhenti selama proses restitusi (Bradley T. Efiord, 2016: 465).

c. Kegunaan

Teknik overcorrection sudah ada selama berpuluh-puluh tahun. Overcorrection mulai sebagai sebuah prosedur yang digunakan untuk menbantu para penyandang disabilitas intelektual untuk mengurangi prilaku menrusak barang-barang, penyerangan fisik, dan prilaku menstimulasi diri, maupun mengajarkan prilaku menggunakan toilet dan prilaku makan dan benar, dan ada penelitian ektensif yang membuktikan keberhasilan prosedur overcorrection dalam hal ini. Contohnya, Foxx dan Azrin menemukan bahwa latihan restitusi efektif dalam mengeliminasi prilaku-prilaku distruptif, seperti melempar barng-barang, menyerang orang lain, dan sua menjerit-jerit. Hasilnya lansung terlihat dan bertahan selama beberapa bulan. Azrin menemukan bahwa overcorrection mengurangi pencurian sebanyak 90\% di antar para penyandang disabilitas intelektual yang diinstitusionalisasikan hanya dalam tiga hari.

Akan tetapi, overcorrection sejak itu telah digunakan dengan beragam populasi mulai dari orang-orang tanpa cacat sampai para penyandang kecacatan berat, termasuk para penderita skizofrenia. Tehnik ini telah digunakan oleh para guru sebagai tehnik menajemen kelas. Overcorrection adalah sebuah prosedur yang dapat digunakan dengan mudah oleh mereka yang tidak memiliki pelatihan konseling formal (Bradley T. Efiord, 2016: 470).

\section{KESIMPULAN}

Konseling behavior dengan tehnik punishment overcorrection saat ini dapat dijadikan salah satu aternatif dari pemberian layanan bimbingan kepada siswa sebagaimana tujuan dari konseling ini dapat mengubah perilaku siswa dari maladaptife menjadi adaptif. Sehingga apapun masalah siswa yang berkaitan dengan perubahan sikap dan pola pikit tentunya diarahkan untuk melakukan atupun pemberian konseling behavior. Dengan pemberian hukuman atas apa yang diperbuat seorang siswa yang menuntut tanggung jawab, Konseling behavior di rancang untuk menolong siswa mengembangkan cara berfikir yang baru dan positif sehingga diharapkan siswa mampu mengenali dan 
memahami kesalahan-kesalahan pola pikir dan perilakunya yang selama ini salah, dan dapat menuju cara berperilaku dan berfikir yang baik.

Tehnik overcorrection memiliki beberapa kelemahan. Ia membutuhkan banyak waktu di pihak konselor professional dan klien. Hasil-hasil overcorrection tidak cenderung dapat digeneralisasikan ke prilaku-prilaku yang lain yang diperlihatkan oleh individu yang bersangkutan atau ke individuindividu yang lain yang melihat prosedur tersebut. Oleh karena itu, beberapa generalisasi dapat didorong dengan memvariasi setting di mana penanganan terjadi dan orang yang mengadministrasikan penanganan. Motivasi orangtua untuk mengimplementasikan tehnik overcorrection mungkin sedangsedang saja karena tehnik ini menduduki peringkat empat dari enam strategi manajemen prilaku yang lazim digunakan dalam kaitannya dengan tinggkat penerimaan orangtua.

\section{DAFTAR PUSTAKA}

Abdul Rahman Sholeh. (2005). Pendidikan Agama dan pengembangan untuk Bangsa. Jakarta: PT. Raja Grafindo Persada.

Bradley T. Efiord. (2016). 40 Teknik yang harus diketahui setiap konselor. Yogyakarta: Pustaka Pelajar.

Gantina Komalasari. (2011). Teori dan Teknik Konseking. Jakarta: Indeks.

Gerald Corey. (2005). Teori dan Peraktek Konseling dan Psikoterapi. Bandung: PT. Refika Aditama.

Mahmud. (2011). Metode Penelitian Pendidikan. Bandung: Pustaka Setia.

Prayitno dan Erman Amti. (2004). Dasar-dasar Bimbingnan dan Konseling. Jakarta: Rieneka Cipta.

Prayitno. (2004). Dasar-dasar Bimbingnan dan Konseling. Jakarta: Rieneka Cipta.

Saifudin Azwar. (2003). Sikap Manusia. Jakarta: Pustaka Pelajar.

Samuel T. Gladding. (2012). Konseling Profesi yang Menyeluruh. Jakarta: Indeks.

Singgih Gunarsa. (1981). Psikologi Remaja. Jakarta: BPK Gunung Mulia.

Supriyo. (t.th.). Studi Kasus Bimbingan Konseling. Semarang: CV. Niuew Setapa.

Suryosubroto. (2009). Proses Belajar di Sekolah. Jakarta: PT Reineka Cipta.

UU No 20 Tahun 2003 Tentang Sistem Pendidikan Nasional 